\title{
Content and composition of the essential oil of Artemisia annua in two harvest times
}

\author{
Paula Tatiana Lopes Seixas ${ }^{\mathrm{a}}$, Henrique Guilhon Castro ${ }^{\mathrm{b} *}$, Luiz Claudio Almeida Barbosa ${ }^{\mathrm{a}}$, \\ Antonio Jacinto Demuner ${ }^{\mathrm{a}}$, Marcelo Coutinho Picanço ${ }^{\mathrm{a}}$
}

a Federal University of Viçosa (UFV), Brasil
${ }^{\mathrm{b}}$ Federal University of Juiz de Fora (UFJF), Brasil
${ }^{*}$ Autor correspondente (hg.castro@uol.com.br)

\section{N F O}

\section{Keywords}

Artemisia annua essential oil gas chromatography coupled to mass spectrometry medicinal plants

\author{
Palavras-chaves \\ Artemissia апииа \\ óleo essencial \\ cromatografia gasosa \\ espectrometria de \\ massa \\ plantas medicinais
}

\begin{abstract}
A B S T R A C T
Artemisia annua is traditionally used in the treatment for malaria due to presence of the active principle artemisinin. The aim of the present study was to evaluate the essential oil content and chemical composition of A. апnиa submitted to four doses of mineral fertilization in two harvest times. The seedlings of A. апnиa were cultivated in $10 \mathrm{~L}$ pots kept in a greenhouse. The tested doses of mineral fertilization were the following: without fertilization (D0), 50\% of the recommended dose (D1), recommended dose (D2), and $150 \%$ of the recommended dose (D3). The samples for extracting the essential oils were collected at 60 and 125 days after transplantation (DAT). The essential oil was obtained by hydrodistillation using a Clevenger-type apparatus. Identification and relative percentage of the compounds of the essential oil were performed by gas chromatography coupled to mass spectrometry. The highest essential oil content obtained was $0.81 \%$ using the dose D0 at 60 DAT. The increase of the dose of mineral fertilization indicated a disadvantage with the reduction of the essential oil content in the two harvesting times. The major constituents found in the essential oil were camphor and borneol. The results indicate that A. annua could be an alternative source of borneol and camphor, active component with use in the chemical and pharmaceutical industry.
\end{abstract}

\section{R E S U M O}

Conteúdo e composição do óleo essencial da Artemisia annua em duas épocas de colheita.

Artemisia annua é utilizada tradicionalmente para o tratamento da malária devido à presença do princípio ativo artemisinina. O objetivo do presente estudo foi avaliar o teor e a composição química do óleo essencial de A. апnиa submetida a quatro doses de adubação mineral em duas épocas de colheita. As mudas de A. аnnua foram cultivadas em vasos de $10 \mathrm{~L}$ mantidas em casa de vegetação. As doses testadas de fertilização mineral foram as seguintes: sem fertilização (D0), 50\% da dose recomendada (D1), dose recomendada (D2) e $150 \%$ da dose recomendada (D3). As amostras para extração dos óleos essenciais foram coletadas aos 60 e 125 dias após o transplante (DAT). O óleo essencial foi obtido por hidrodestilação usando um aparelho do tipo Clevenger. A identificação e a porcentagem relativa dos compostos do óleo essencial foram realizadas por cromatografia gasosa acoplada à espectrometria de massa. O maior teor de óleo essencial obtido foi de $0,81 \%$ na dose D0 aos 60 DAT. O aumento da dose de adubação mineral indicou uma desvantagem com a redução do teor de óleo essencial nas duas épocas de colheita. Os constituintes majoritários encontrados no óleo essencial foram cânfora e borneol. Os resultados indicam que A. annua pode ser uma fonte alternative de borneol e cânfora, princípios ativos com uso na indústria química e farmacêutica. 


\section{INTRODUCTION}

Asteraceae is the largest family of flowering plants, consisting of 1,535 genera and approximately 23,000 species, many of which are used for medicinal purposes (Fakim, 2006; Pellicer et al., 2008). The genera Artemisia, with 800 species distributed worldwide, is industrially important due to its antifungal, insecticidal, allelopathic, and antibacterial properties, among others (Malik et al., 2009; Chauhan et al., 2010; Lutz et al., 2008).

The species Artemisia annua L. (A. апnиa) presents an annual cycle and is a known natural producer of artemisinin, a sesquiterpene with antimalarial property (Yarnell \& Abascal, 2004; Balunas \& Kinghorn, 2005; Cavar et al., 2012; Herrmann et al., 2013).

Among the secondary metabolites of plants are essential oils which are complex mixtures that may contain more than a hundred organic compounds. The chemical constituents of these oils may belong to the most diverse classes of compounds. However the terpenes are the most commonly found compounds (Gonçalves et al., 2003; Castro et al., 2010; Veloso et al., 2014). The monoterpenes, sesquiterpenes, and oxygen derivatives of these substances are the predominant constituents of essential oils from several eucalyptus species (Barbosa et al., 2016; Ribeiro et al., 2018). In most cases the biological activity of a particular essential oil may be related to the major constituent (Bakkali E Idaomar, 2008), although synergism may also occur between some compounds (Filomeno et al., 2017).

Within this context, the objective of this work was to evaluate the content and composition of the essential oil of $A$. аппиа submitted to four doses of mineral fertilization in two harvest times, as well as to identify the major constituents of the essential oil

\section{MATERIAL E MÉTODOS}

\section{Preparation of seedlings and cultivation}

The experiment was conducted in the Federal University of Viçosa- UFV, in Viçosa-MG, Brazil (20 $0^{\circ} 76^{\prime} 26^{\prime}$ 'S and $42^{\circ} 86^{\prime} 40^{\prime}$ ' $\mathrm{W}$ with average altitude of $690 \mathrm{~m}$ ), in a greenhouse from the period from March 10 of 2013 to November 10 of 2013. The voucher for species of A. annua was deposited in the UFV herbarium under the identification VIC15592.

A. аппиа cv. Artemis was propagated through hybrid seeds resulting from plant breeding. The seedlings were grown in plastic cups with a volume of $300 \mathrm{~mL}$ using commercial substrate. After rooting of the seedlings, the transplantation was carried out in pots with a volume of $10 \mathrm{~L}$ kept within a greenhouse.

The experiment was installed in a completely randomized design in a factorial scheme $(4 \times 2)$, with three repetitions for extraction of essential oil. The plots consisted of a pot $(10 \mathrm{~L})$, with two plants. The plants were cultivated in four doses of fertilization (NPK): without fertilization (D0), 50\% of the recommended dose (D1), recommended dose (D2), and $150 \%$ of the recommended dose (D3). The evaluations were carried out in two harvest times: 60 and 125 days after transplantation (DAT). The substrate used in the pots for plant cultivation was constituted by soil classified as Red Latosol Dystrophic (Santos et al., 2006), collected in the layer of $0-20 \mathrm{~cm}$.

The sources of nitrogen, phosphorus, and potassium used were ammonium sulfate P.A. $(21 \% \mathrm{~N})$, simple superphosphate P.A. $\left(18 \% \mathrm{P}_{2} \mathrm{O}_{5}\right)$, and potassium chloride P.A. $\left(60 \% \mathrm{~K}_{2} \mathrm{O}\right)$, respectively. The doses of mineral fertilizer used in the experiment were the following $\left(\mathrm{Kg} \mathrm{pot}^{-1}\right)$ : nitrogen $=0.0035$ (D1), 0.007 (D2), 0.01 (D3); phosphorus $=0.02$ (D1), 0.04 (D2), 0.06 (D3); potassium $=0.0015$ (D1), 0.003 (D2), 0.0045 (D3).

\section{Essential oil analysis}

The leaves of A. annua were separated into three portions of $100 \mathrm{~g}$. The essential oils from such portions were then extracted by hydrodistillation, for a period of two hours in triplicate, using a Clevengertype apparatus. The oils were separated from the aqueous phase with pentane PA (C5H12). The organic fractions obtained were pooled and dried over anhydrous magnesium sulfate, filtered, and the solvent removed under reduced pressure in a rotary evaporator at $40{ }^{\circ} \mathrm{C}$.

The components of essential oils were analyzed by Shimadzu GCMS-QP5050A apparatus, equipped with a DB-5-fused silica column (30 $\mathrm{m} \times$ $0.25 \mathrm{~mm}$, film thickness of $0.25 \mu \mathrm{m}$ ) and coupled to a mass detector. The following chromatographic conditions were employed: Helium as carrier gas under a flow of $1.8 \mathrm{~mL} \mathrm{~min}^{-1}$; injector temperature of $220{ }^{\circ} \mathrm{C}$; initial oven temperature of $40^{\circ} \mathrm{C}$, isothermal for $2 \mathrm{~min}$., followed by heating at $3{ }^{\circ} \mathrm{C} \mathrm{min}$ 1 to $240{ }^{\circ} \mathrm{C}$, then remaining isothermal for $15 \mathrm{~min}$; sample injection volume of $1.0 \mu \mathrm{L}(10 \mathrm{mg} \mathrm{mL}-1$ in dichloromethane); split ratio of 1:10; and column pressure of $100 \mathrm{kPa}$ (Barbosa et al., 2012).

The quantification of the essential oil components was carried out with Shimadzu GC-17A equipment fitted with a flame ionization detector (FID) and a SBP5-supelco-fused silica capillary column $(30 \mathrm{~m} \times 0.25 \mathrm{~mm}$, film thickness of 0.25 $\mu \mathrm{m})$. Chromatographic conditions were identical to 
those used for CG-MS analyses, except for the fact that the carrier gas used was nitrogen.

The identification of essential oil components was performed through a comparison of their retention indexes (RI) (Adams, 2007) relative to a standard alkane series (C9-C27) as well as through comparison of their mass spectrum with those available in the Nist library database (Maia \& Andrade, 2009; Syarul et al., 2010).

\section{Statistical analysis}

The data of the essential oil content were subjected to variance and regression analysis. For qual- itative fator (harvest times), the means were compared through the Tukey test and regression equations were adjusted for the quantitative factor (doses of mineral fertilization). The regression equations were adjusted based on the "t" test of the coefficients at 5 or $1 \%$ probability and in the coefficient of determination. The analysis was performed in the MINITAB 17 computer system.

\section{RESULTADOS E DISCUSSÃO}

\section{Essential oil contente}

The analysis of variance for the variable essential oil content is shown in table 1 .

Table 1 - Analysis of variance for the variable essential oil content from Artemisia annua in two harvest times (Times) and four doses of mineral fertilization (doses).

\begin{tabular}{lcccc}
\hline SV & DF & SS & MS & F \\
\hline Times & 1 & 0.06827 & 0.068267 & $10.15^{* *}$ \\
Doses & 3 & 0.50258 & 0.167528 & $24.91^{* *}$ \\
Times x doses & 3 & 0.0894 & 0.0298 & $4.43^{* *}$ \\
Error & 16 & 0.1076 & 0.006725 & \\
Total & 23 & 0.76785 & & \\
** significant at 1\% probability $(\mathrm{p}<0.01)$ & & & &
\end{tabular}

According to the analysis of variance, significant interaction was found $(\mathrm{p}<0.01)$ among the factors harvest times and doses of mineral fertilization. Thus, unfolding of interaction "harvest times $\mathrm{x}$ doses of mineral fertilization" was performed to compare the levels of one factor within the levels of the other factor. In the factor harvest times (qualitative factor) the means were compared by Tukey test. In the factor doses of mineral fertilization (quantitative factor) were adjusted regression equations (Table 2).

Table 2 - Mean values of essential oil content (\%), regression equations, and coefficient of determination (r2) of A. апnиa, in four doses of mineral fertilization (D0, D1, D2 and D3) and two harvest times (60 and 125 days after transplantation- DAT). Viçosa-MG, 2017.

\begin{tabular}{|c|c|c|c|c|c|c|}
\hline \multirow[b]{2}{*}{ Harvest times } & \multicolumn{4}{|c|}{ Doses of mineral fertilization } & \multirow[b]{2}{*}{ Regression equations } & \multirow[b]{2}{*}{$\mathbf{r}^{2}(\%)$} \\
\hline & D0 & D1 & D2 & D3 & & \\
\hline 60 DAT & $0.81 \mathrm{a}$ & $0.60 \mathrm{a}$ & $0.59 \mathrm{a}$ & $0.39 \mathrm{a}$ & $\mathrm{y}=0.915-0.1277 * * d$ & 69.44 \\
\hline $125 \mathrm{DAT}$ & $0.54 \mathrm{~b}$ & $0.63 \mathrm{a}$ & $0.58 \mathrm{a}$ & $0.21 \mathrm{a}$ & $y=0.6447-0.2073 * d$ & 46.39 \\
\hline
\end{tabular}

Means followed by the same letter in the column do not differ by Tukey test $(\mathrm{P}>0.05)$. ** = significant at $1 \%$ probability by the " $\mathrm{t}$ " test $(\mathrm{P}<0.01)$; or $*=$ significant at $5 \%$ probability by the "t" test $(\mathrm{P}<0.05)$.

The essential oil contents in the two harvest times varied from $0.21 \%$ to $0.81 \% \mathrm{~m} / \mathrm{m}$. Significant difference $(\mathrm{P}<0.05)$ in the essential oil content only was observed for the dose D0, where the first harvest time presented value (0.81) statistically higher than the value of second harvest $(0.54)$ (Table 02).

A tendency of decrease in the essential oil content was observed as the dose of NPK increased, according to the adjusted regression equations in both harvests. The adjusted linear regression model presented a negative angular coefficient, indicating that with the increase of the dose of mineral fertilization, there was reduction in the essential oil content (Table 2).

It is worth emphasizing that the essential oil content in the plant can be influenced by the time of collection and the stage of development of the plant, because during the growth phase there is a greater demand for nutrients. In this present study, was observed an increase of average value of essential oil content in the first harvest time (60 DAT) 
compared to the second harvest considering the four doses of fertilization.

The application of fertilizers to aromatic plants usually affects the production of essential oils (Nurzynska-Wierdak, 2013). Thus, an evaluation of the requirements of each species and the appropriate management of fertilization are necessary (Martins et al., 2007; Seixas et al., 2013).

\section{Identification of chemical constituents}

The qualitative analysis of the constituents of the essential oils was performed by GC-MS. The compounds identification was carried out comparison with data found in the mass spectra databases and by their retention indexes (Tables 03 and 04) (Adams, 2007).

Table 3 - Major components of the essential oils from A. annua at first harvest time (60 days after transplantation) and four doses of mineral fertilization

\begin{tabular}{|c|c|c|c|c|c|c|}
\hline \multirow{2}{*}{ Major components } & \multirow{2}{*}{$\mathbf{R I}^{\mathbf{a}}$} & \multirow{2}{*}{$\mathbf{R} \mathbf{I}^{\mathbf{b}}$} & D0 & D1 & D2 & D3 \\
\hline & & & \multicolumn{4}{|c|}{ Relative peak áreas $(\%)^{\mathrm{c}}$} \\
\hline 1,8 - cineole & 1027 & 1026 & $2.37 \pm 0.03$ & $2.37 \pm 0.05$ & $2.00 \pm 0.05$ & $2.08 \pm 0.02$ \\
\hline Camphor & 1144 & 1141 & $\operatorname{tr}$ & $\operatorname{tr}$ & $26.56 \pm 0.03$ & $26.70 \pm 0.03$ \\
\hline Pinocarvone & 1160 & 1160 & $\operatorname{tr}$ & $\operatorname{tr}$ & $\operatorname{Tr}$ & $2.33 \pm 0.00$ \\
\hline Borneol & 1164 & 1165 & $33.07 \pm 0.12$ & $33.08 \pm 0.15$ & $1.84 \pm 0.01$ & $\operatorname{tr}$ \\
\hline Terpinen-4-ol & 1150 & 1174 & $3.32 \pm 0.03$ & $3.33 \pm 0.09$ & $\operatorname{tr}$ & $\operatorname{tr}$ \\
\hline (E)-Caryophyllene & 1417 & 1417 & $6.06 \pm 0.02$ & $6.06 \pm 0.02$ & $6.16 \pm 0.02$ & $7.39 \pm 0.12$ \\
\hline (E)- $\beta$-Farnesene & 1458 & 1454 & $4.99 \pm 0.15$ & $4.99 \pm 0.01$ & $5.99 \pm 0.08$ & $5.41 \pm 0.23$ \\
\hline$\beta$-Chamigrene & 1475 & 1476 & $\operatorname{tr}$ & $\operatorname{tr}$ & $\operatorname{tr}$ & - \\
\hline$\alpha$-Amorphene & 1482 & 1483 & $\operatorname{tr}$ & $\operatorname{tr}$ & $21.99 \pm 0.41$ & $21.93 \pm 0.13$ \\
\hline Germacrene D & 1482 & 1484 & $18.28 \pm 0.58$ & $18.28 \pm 0.06$ & $1.66 \pm 0.05$ & $1.61 \pm 0.01$ \\
\hline Bicyclogermacrene & 1495 & 1500 & $1.34 \pm 0.25$ & $1.34 \pm 0.00$ & $0.56 \pm 0.00$ & $0.27 \pm 0.02$ \\
\hline Caryophyllenyl alcohol & 1575 & 1570 & $2.44 \pm 0.02$ & $2.44 \pm 0.02$ & $3.15 \pm 0.05$ & $2.78 \pm 0.03$ \\
\hline allo-Aromadendrene epoxide & 1630 & 1638 & $\operatorname{tr}$ & $\operatorname{tr}$ & $2.20 \pm 0.00$ & $2.10 \pm 0.02$ \\
\hline 1-epi-Cubenol & 1624 & 1627 & $\operatorname{tr}$ & $\operatorname{tr}$ & $2.82 \pm 0.00$ & $1.71 \pm 0.02$ \\
\hline$\beta$-Cedren-9-one & 1630 & 1630 & $1.78 \pm 0.25$ & $1.78 \pm 0.05$ & $\operatorname{tr}$ & $\operatorname{tr}$ \\
\hline epi- $\alpha$-Cadinol & 1646 & 1638 & $1.64 \pm 0.01$ & $1.64 \pm 0.02$ & $2.20 \pm 0.12$ & $\operatorname{tr}$ \\
\hline$\alpha$-Bisabolol & 1687 & 1685 & $1.51 \pm 0.04$ & $1.51 \pm 0.01$ & $1.78 \pm 0.02$ & $0.34 \pm 0.00$ \\
\hline Identified (\%) & & & 77.43 & 76.82 & 78.91 & 74.65 \\
\hline
\end{tabular}

${ }^{\mathrm{a}}$ calculated retention index; ${ }^{\mathrm{b}}$ retention index described in the literature (Adams 2007); ${ }^{\mathrm{c}}$ All values reported as an average of three replicates; tr - trace compound (less than 1.0\%); D0: without fertilization; D1: $50 \%$ of the recommended dose; D2: recommended dose; D3: 150\% of the recommended dose.

Table 4 - Major components of the essential oils from A. annua at second harvest time (125 days after transplantation) and four doses of mineral fertilization.

\begin{tabular}{|c|c|c|c|c|c|c|}
\hline \multirow{2}{*}{ Major components } & \multirow{2}{*}{$\mathbf{R I c}^{\mathbf{a}}$} & \multirow{2}{*}{$\mathbf{R I}^{\mathbf{b}}$} & D0 & D1 & D2 & D3 \\
\hline & & & \multicolumn{4}{|c|}{ Relative peak áreas $(\%)^{\mathrm{c}}$} \\
\hline 1,8 - cineole & 1027 & 1026 & $0.90 \pm 0.02$ & $2.37 \pm 0.06$ & $2.87 \pm 0.02$ & $4.05 \pm 0.00$ \\
\hline Camphor & 1144 & 1141 & $14.72 \pm 0.02$ & $32.72 \pm 0.08$ & $31.80 \pm 1.23$ & $56.79 \pm 0.28$ \\
\hline Pinocarvone & 1160 & 1160 & $\operatorname{tr}$ & $\operatorname{tr}$ & $\operatorname{tr}$ & $7.54 \pm 0.05$ \\
\hline Borneol & 1164 & 1165 & $0.96 \pm 0.02$ & $1.92 \pm 0.05$ & $0.94 \pm 0.01$ & $\operatorname{tr}$ \\
\hline Terpinen-4-ol & 1150 & 1174 & $\operatorname{tr}$ & $\operatorname{tr}$ & $\operatorname{tr}$ & $1.91 \pm 0.06$ \\
\hline (E)-Caryophyllene & 1417 & 1417 & $5.48 \pm 0.05$ & $7.91 \pm 0.01$ & $7.79 \pm 0.85$ & $3.71 \pm 0.03$ \\
\hline (E)- $\beta$-Farnesene & 1458 & 1454 & $4.02 \pm 0.00$ & $4.45 \pm 0.02$ & $5.16 \pm 0.84$ & $2.47 \pm 0.00$ \\
\hline$\beta$-Chamigrene & 1475 & 1476 & $\operatorname{tr}$ & $2.04 \pm 0.21$ & $2.01 \pm 0.02$ & $7.67 \pm 0.15$ \\
\hline$\alpha$-Amorphene & 1482 & 1483 & $16.54 \pm 0.33$ & $\operatorname{tr}$ & $\operatorname{tr}$ & $0.69 \pm 0.00$ \\
\hline Germacrene D & 1482 & 1484 & $1.59 \pm 0.00$ & $19.68 \pm 0.41$ & $20.99 \pm 0.12$ & $0.56 \pm 0.00$ \\
\hline Bicyclogermacrene & 1495 & 1500 & $0.43 \pm 0.00$ & $2.25 \pm 0.01$ & $2.64 \pm 0.03$ & $0.73 \pm 0.02$ \\
\hline Caryophyllenyl alcohol & 1575 & 1570 & $2.20 \pm 0.02$ & $2.59 \pm 0.02$ & $2.22 \pm 0.02$ & $1.08 \pm 0.00$ \\
\hline allo-Aromadendrene epoxide & 1630 & 1638 & $\operatorname{tr}$ & $\operatorname{tr}$ & $\operatorname{tr}$ & $0.77 \pm 0.05$ \\
\hline 1-epi-Cubenol & 1624 & 1627 & $1.49 \pm 0.01$ & $1.77 \pm 0.23$ & $1.46 \pm 0.25$ & $0.48 \pm 0.00$ \\
\hline$\beta$-Cedren-9-one & 1630 & 1630 & $1.51 \pm 0.01$ & $2.07 \pm 0.63$ & $1.87 \pm 0.21$ & $\operatorname{tr}$ \\
\hline epi- $\alpha$-Cadinol & 1646 & 1638 & $1.40 \pm 0.01$ & $0.81 \pm 0.32$ & $0.68 \pm 0.14$ & $\operatorname{tr}$ \\
\hline$\alpha$-Bisabolol & 1687 & 1685 & $34.44 \pm 0.24$ & $1.43 \pm 0.01$ & $1.05 \pm 0.00$ & $\operatorname{tr}$ \\
\hline Identified (\%) & & & 86.68 & 82.01 & 81.48 & 88.45 \\
\hline
\end{tabular}

${ }^{\mathrm{a}}$ calculated retention index; ${ }^{\mathrm{b}}$ retention index described in the literature (Adams 2007); ${ }^{\mathrm{c}}$ All values reported as an average of three replicates; tr - trace compound (less than 1.0\%); D0: without fertilization; D1: 50\% of the recommended dose; D2: recommended dose; D3: 150\% of the recommended dose. 
In the essential oils extracted from A. аппиа, a total of 17 components were identified with the major components shown in Table 03 and 04. The monoterpenes camphor and borneol were the major constituents in the oils of $A$. апnиа. In the first harvest, using doses D0 and D1, the presence of camphor not was observed, while in the second harvest using dose D3, 56.79\% of camphor was detected. This variation in the camphor content indicates that in this species an increase of the dose of fertilization NPK favored an increase in the camphor content and that this increase was more pronounced during the second harvest.

The sesquiterpenes germacrene $\mathrm{D}$ and $\alpha$-amorphene were also identified in high concentrations in the oils from plants of both harvesting times. The increase in NPK fertilization did not favor the increase of $\alpha$-amorphene and germacrene $\mathrm{D}$ contents. The variation in the content of these compounds occurred at random in the oils from the two harvesting (60 and 125 DAT). The highest content of germacrene D was $20.99 \%$ for plants submitted in the D2 treatments at 125 DAT (Figure 01). The $\alpha$ amorphene compound had its highest concentration in the essential oil when the plants were submitted to treatment D2 at $60 \mathrm{DAT}$, at $21.99 \%$. The sesquiterpene $\alpha$-bisabolol was found in small quantities $(<2 \%)$ in almost all samples, except in the oil obtained from plants subjected to D0 treatment and harvested at 125 DAT, which presented $34.44 \%$ of this compound (Table 03 and 04).

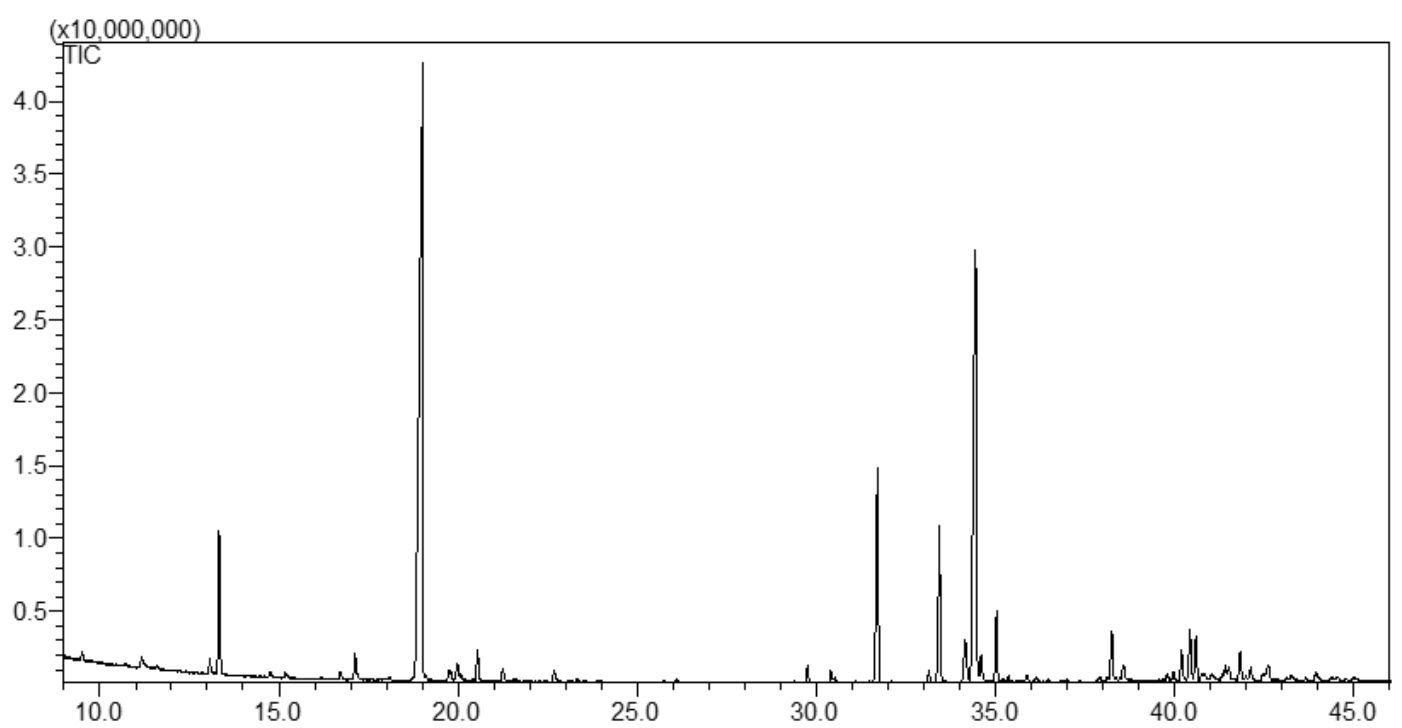

Figure 1 - Chromatogram of the essential oil from leaves of Artemisia annua with dose NPK (D2) at 125 days after transplantation. 1: 1,8-cineole (2,87\%); 2 : camphor (31,80\%); 3: E-caryophyllene (7,79\%); 4: (E)- $\beta$-farnesene $(5,16 \%) ; 5:$ Germacrene D (20,99\%)

Judging from the results obtained, this species can be used as a source of borneol or camphor, depending on the dosage used during fertilization and the time of harvest. Such compounds are important, considering that borneol derived from pine oil is used as a disinfectant and deodorant. Camphor has application as an anesthetic, expectorant, and antipruritic. In fact, considering that $\alpha$-bisabolol has been reported to have several biological activities, including anti-inflammatory, antimicrobial, and leishmanicidal (Lopez et al., 2015), the results reported here are also relevant considering that this plant can be cultivated under controlled conditions to maximize the production of this important sesquiterpene.

Geranyl diphosphate is a precursor compound of monoterpenes and may produce 1,8-cineole, sabinene, sabinene hydrate, linalool, and limonene, by means of enzymatic reactions (Figure 02). The interconversion of the components is determined genetically and can be affected by agronomic factors and the stage of plant development. For example, is it apparent from Table 03 that at D1 and 60 DAT, the oil is rich in borneol and has no camphor. After another 65 days of cultivation (125 DAT) under the same fertilization procedure, the borneol content decreases to $1.92 \%$ while camphor yield is $32.72 \%$ (Table 04) (Figure 02). The oxidation of borneol as the plant matures can explain this variation. Such variation can also be explained considering Figure 02 , where the intermediate cation 3 can generate in one way compounds 7-9 in competition to 4-6. 


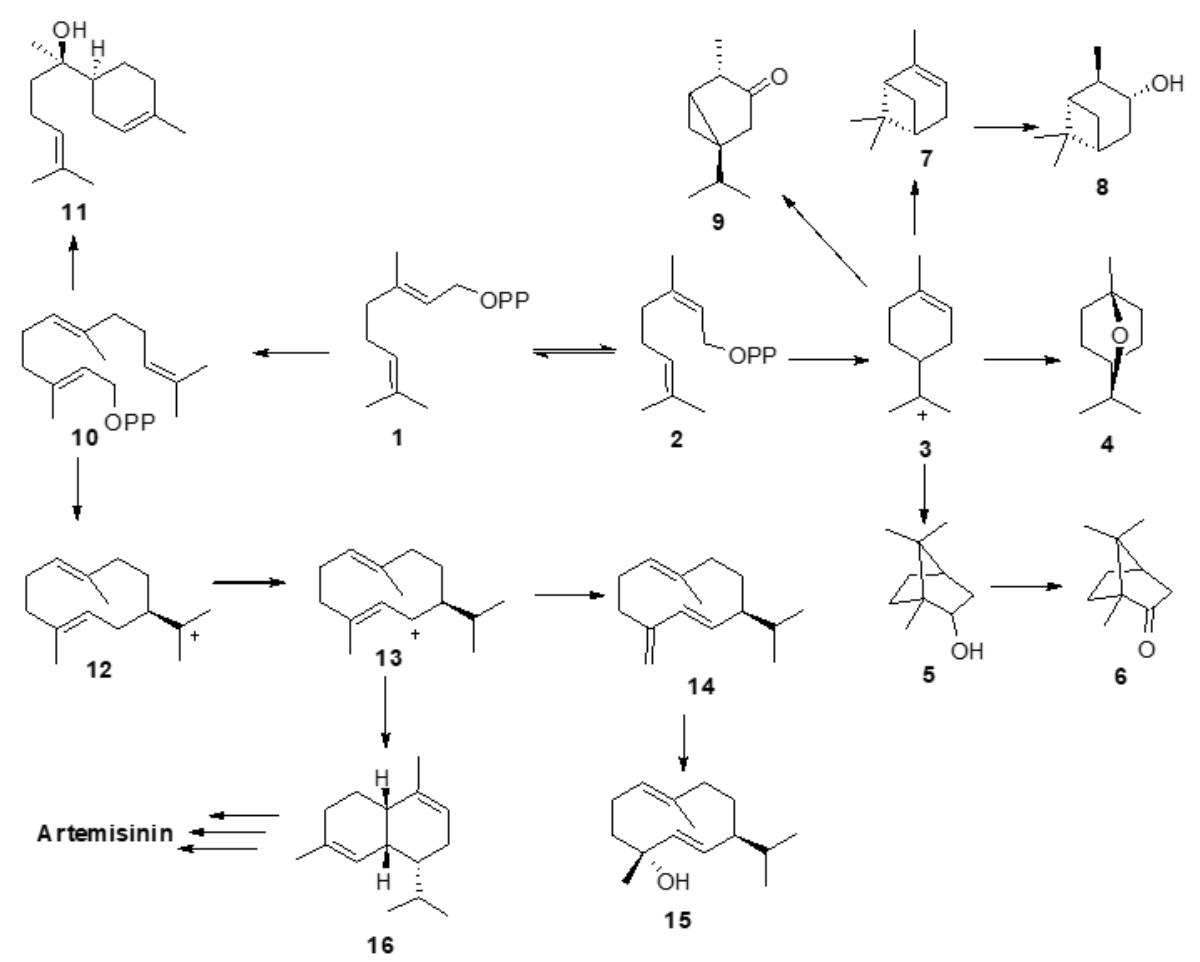

Figure 2 - Biosynthetic routes for the formation of the main components of Artemisia oils. 1: Geranyl-OPP; 2 : Neryl-OPP; 3: Terpenylic cation; 4: 1,8-Cineole; 5: Borneol; 6: Camphor; 7: $\beta$-pinene; 8: Pinocampheol; 9 : trans-Thujone; 10: Farnesyl-OPP; 11: $\alpha$-Bisabolol; 12: Germacrenylic cation; 13: Germacrenylic cation rearranged; 14: Germacrene D; 15: Germacrene D-4-ol; 16: $\alpha$-Amorphene.

Some of the variation in the chemical composition may be related to potassium $(\mathrm{K})$, because it is involved in the synthesis of aromatic compounds through the activation of several enzymes. The conditions which led to the increase in the concentration of this nutrient may have provoked stimulation in the enzymatic activities, consequently altering the composition of the oils (Garlet et al., 2007).

The study of essential oil of Artemisia species is important for the characterization of the genetic resources which are conductive to the selection of species. The knowledge of these genetic characteristics in the plant of interest as well as information pertaining to the cultivation environment contributes to the selection of genotypes that are more adapted to specific habitats (Castro et al., 2016; Camêlo et al., 2011; Nascimento et al., 2011).

In this sense, biotic and abiotic factors, including genetic variation, plant nutrition, geographic location, seasonal variations, and stress during growth or maturity, influence the yield and composition of the essential oil and its biological properties (Raut \& Karuppayil, 2014).

\section{CONCLUSIONS}

The highest essential oil content in A. апnиа $(0.81 \%)$ was observed in the D0 treatment at 60
DAT, while the lowest oil content $(0.21 \%)$ was found in the D3 treatment at 125 DAT. Significant difference $(\mathrm{P}<0.05)$ in the essential oil content only was observed for the dose D0.

For A. annua the increase of the dose of mineral fertilization indicated a disadvantage with the reduction of the essential oil content in the two harvesting times. Therefore, the increase of NPK fertilization dose did not increase the essential oil content of A. апnиa and is not an advantage for this purpose.

In general, the variation of the composition of the essential oil under greenhouse conditions, in two harvesting times (60 and 125 DAT) and using four doses of mineral fertilization, occurred at random.

The results indicate that $A$. annua could be an alternative source of borneol and camphor, biological active component with use in the chemical and pharmaceutical industry.

The effect of NPK fertilization on the composition of the essential oil of $A$. annua requires development of other studies, taking into account that the production of secondary metabolites is not always stimulated with NPK fertilization due to the influence of physiological factors and the genetic constitution of the plant. 


\section{ACKNOWLEDGEMENTS}

We are grateful to the following Brazilian agencies: Conselho Nacional de Desenvolvimento Científico e Tecnológico $(\mathrm{CNPq})$ for research fellowships (AJD, LCAB, MCP); Fundação de Amparo à Pesquisa de Minas Gerais (FAPEMIG) for financial support and Coordenação de Aperfeiçoamento de Pessoal de Nível Superior (CAPES) for research fellowship (PTLS).

\section{REFERÊNCIAS BIBLIOGRÁFICAS}

ADAMS, R.P. Identification of essential oil components by gas chromatography /mass spectrometry. 4th ed. Carol Stream: Allured Publishing Corporation, 804p. 2007.

BAKKALI, F.; AVERBECK, S.; AVERBECK, D.; IDAOMAR, M. Biological effects of essential oils- A review. Food and Chemical Toxicology, v.46, p.446-475, 2008. https://doi.org/10.1016/j.fct.2007.09.106

BALUNAS, M.J.; KINGHORN, A.D. Drug discovery from medicinal plants. Life Sciences, v.78, n.5, p.431-441, 2005.

https://doi.org/10.1016/j.lfs.2005.09.012

BARBOSA, L.C.A.; FILOMENO, C.A.; TEIXEIRA, R.R. Chemical variability and biological activities of Eucalyptus spp. essential oils. Molecules, v.21, n.12, p.1671-1704, 2016.

https://doi.org/10.3390/molecules21121671

BARBOSA, L.C.A.; DEMUNER, A.J.; CLEMENTE, A.D.; PAULA, V.F.; ISMAIL, F.M.D. Seasonal variation in the composition of volatile oils from Schinus terebinthifolius RADDI. Química Nova, v.30, n.8, p.1959-1965, 2007. https://dx.doi.org/10.1590/S0100-404220070008000

CAMÊLO, L.C.A.; BLANK, A.F.; EHLERT, P.A.D.; CARVALHO, C.R.D.; ARRIGONI-BLANK, M.F.; MATTOS, J. Caracterização morfológica e agronômica de acessos de erva cidreira-brasileira [Lippia alba (Mill.) N. E. Br.]. Scientia Plena, v.7, n.5, p. 1-8, 2011.

CASTRO, H.G.; PERINI, V.B.M.; SANTOS, G.R.; LEAL, T.C.A.B. Avaliação do teor e composição do óleo essencial de Cymbopogon nardus (L.) em diferentes épocas de colheita. Revista Ciência Agronômica, v.41, n.2, p.308-314, 2010.

https://dx.doi.org/10.1590/S1806-66902010000200020

CASTRO, H.G.; VELOSO, R.; CARDOSO, D.P.; CHAGAS JÚNIOR, A.F.; CHAGAS, L.F.B. Caracterização botânicaagronômica e do óleo essencial de acessos de manjericão. Revista Verde de Agroecologia e Desenvolvimento Sustentável, v.11, n.4, p.01-06, 2016.

https://doi.org/10.18378/rvads.v11i4.4130

CAVAR, S.; MAKSIMOVI, M.; VIDIC, D.; PARIC, A. Chemical composition and antioxidant and antimicrobial activity of essential oil of Artemisia annua L. from Bosnia. Industrial Crops and Products, v.37, n.1, p.479-485, 2012. https://doi.org/10.1016/j.indcrop.2011.07.024

CHAUHAN, R.S.; KITCHLU, S.; RAM, G.; KAUL, M.K.; TAVA, A. Chemical composition of capillene chemotype of Artemisia dracunculus L . from North-West Himalaya. Industrial Crops and Products, v.31, n.3, p.546-549, 2010 https://doi.org/10.1016/j.indcrop.2010.02.005

FAKIM, A.G. Medicinal plants: Traditions of yesterday and drugs of tomorrow. Molecular Aspects of Medicine, v.27, n.1, p.1-93, 2006. https://doi.org/10.1016/j.mam.2005.07.008

FILOMENO, C.A.; BARBOSA, L.C.A.; TEIXEIRA, R.R.; PINHEIRO, A.L.; FARIAS, E.S.; SILVA, E.M.P.; PICANÇO, M.C. Corymbia spp. and Eucalyptus spp. essential oils have insecticidal activity against Plutella $x y$ lostella. Industrial Crops and Products, v.109, n.15, p.374383, 2017.

https://doi.org/10.1016/j.indcrop.2017.08.033

GARLET, T.M.B.; SANTOS, O.S.; MEDEIROS, S.L.P.; MANFRON, P.A.; GARCIA, D.C.; BORCIONI, E.; FLEIG, V. Produção e qualidade do óleo essencial de menta em hidroponia com doses de potássio. Ciência Rural, v.37, n.4, p.956-962, 2007.

https://doi.org/10.1590/S0103-84782007000400006

GONÇALVES, L.A.; BARBOSA, L.C.A.; AZEVEDO, A.A.; CASALI, V.W.D.; NASCIMENTO, E.A. Produção e composição do óleo essencial de alfavaquinha (Ocimum selloi Benth.) em resposta a dois níveis de radiação solar. Revista Brasileira de Plantas Medicinais, v.6, n.1, p.8-14, 2003.

HERRMANN, S.; JESSING, K.K.; JORGENSEN, N.O.G.; CEDERGREEN, N.; KANDELER, E.; STROBEL, B.W. Distribution and ecological impact of artemisinin derived from Artemisia annua L. in an agricultural ecosystem. Soil Biology and Biochemistry, v.57, p.164-172, 2013. https://doi.org/10.1016/j.soilbio.2012.08.011

LOPEZ, V.C.; MÁRQUEZ, F.M.; MOLL, C.N.; ESPINOSA, G.M.; SÁEZ, V.D.; SÁNCHEZ, J.M. (-)- $\alpha$-Bisabolol, a promising oral compound for the treatment of visceral leishmaniasis. Journal of Natural Products, v.78, n.6, p.1202-1207, 2015. https://doi.org/10.1021/np5008697

LUTZ, D.L.; ALVIANO, D.S.; ALVIANO, C.S.; KOLODZIEJCZYK, P.P. Screening of chemical composition, antimicrobial and antioxidant activities of Artemisia essential oils. Phytochemistry, v.69, n.8, p.1732-1738, 2008. https://doi.org/10.1016/j.phytochem.2008.02.014

MAIA, J.G.S; ANDRADE, E.H.A. Database of the amazon aromatic plants and their essential oils. Química Nova, v.32, n.3, n.595-622, 2009. http://dx.doi.org/10.1590/S0100-40422009000300006

MALIK, A.A.; AHMAD. J.; MIR, S.R.; ALI, M.; ABDIN, M.Z. Influence of chemical and biological treatments on volatile oil composition of Artemisia annua Linn. Industrial Crops and Products, v.30, n.3, p.380-383, 2009. https://doi.org/10.1016/j.indcrop.2009.07.006

MARTINS, F.T.; SANTOS, M.H.; POLO, M.; BARBOSA, L.C.A. Effects of the interactions among macronutrients, plant age and photoperiod in the composition of Hyptis suaveolens (L.) Poit essential oil from Alfenas (MG), Brazil. Flavour and Fragrance Journal, v.22, n.2, p.123-129, 2007.

https://doi.org/10.1002/ffj.1769 
NASCIMENTO, J.C.; BARBOSA, L.C.A.; PAULA, V.F.; DAVID, J.M.; FONTANA, R.; SILVA, L.A.M.;

FRANÇA. R.S. Chemical composition and antimicrobial activity of essential oils of Ocimum canum Sims. and Ocimum selloi Benth. Anais da Academia Brasileira de Ciências, v.83, n.3, p.787-799, 2011.

http://dx.doi.org/10.1590/S0001-37652011005000019

NURZYNSKA-WIERDAK, R. Does mineral fertilization modify essential oil content and chemical composition in medicinal plants? Acta Scientiarum Polonorum, v.12, n.5, p. 3-16, 2013.

PELLICER, J.; GARCIA, S.; GARNATGE, T.; HIDALGO, O.; SILJAK-YAKOVLEV, S.; VALLÈS, J. Molecular cytogenetic characterization of some representatives of the subgenus Artemisia absinthium (genus Artemisia, Asteraceae). Collectanea Botanica, v.27, p.19-27, 2008.

http://dx.doi.org/10.3989/collectbot.2008.v27.2

RAUT, J.S.; KARUPPAYIL, S.M. A status review on the medicinal properties of essential oils. Industrial Crops and Products, v.62, p.250-264, 2014.

http://dx.doi.org/10.1016/j.indcrop.2014.05.055

RIBEIRO, A.V.; FARIAS, E.D.; SANTOS, A.A.; FILOMENO, C.A.; SANTOS, I.B.; BARBOSA, L.C.A.; PICANÇO, M.C. Selection of an essential oil from Corymbia and Eucalyptus plants against Ascia monuste and its selectivity to two non-target organism. Crop Protection, v.110, p.207-213, 2018.

https://doi.org/10.1016/j.cropro.2017.08.014

SANTOS, H.G.; JACOMINE, K.T.; ANJOS, L.H.C.; OLIVEIRA, V.H.; OLIVEIRA, J.B.; COELHO, M.R.; LUMBRERAS, J.F.; CUNHA, T.J.F. Sistema brasileiro de classificação de solos. 2nd ed. Rio de Janeiro: Embrapa, 306p. 2006.

SEIXAS, P.T.L.; CASTRO, H.G.; CARDOSO, D.P.; CHAGAS JÚNIOR, A.F.; NASCIMENTO, I.R.; BARBOSA, L.C.A. Efeito da adubação mineral na produção de biomassa e no teor e composição do óleo essencial do capimcitronela. Bioscience Journal, v.29, n.4, p.852-858, 2013.

SYARUL, N.B.; HAMIDUN, B.; MA'ARUF A.G.; WAN A.W.M.; NORMAH M.N. Analysis of the Chemical Composition of the Essential Oil of Polygonum minus Huds. Using Two-Dimensional Gas Chromatography-Time-ofFlight Mass Spectrometry (GC-TOF MS). Molecules, v.15, p.7006-7015, 2010. https://doi.org/10.3390/molecules15107006

VELOSO, R.A.; CASTRO, H.G.; CARDOSO, D.P.; CHAGAS JÚNIOR, A.F.; CHAGAS, L.F.B. Estudo comparativo entre acessos e cultivares de manjericão no Estado do Tocantins. Revista Verde de Agroecologia e Desenvolvimento Sustentável, v.9, n.4, p.224-229, 2014. http://dx.doi.org/10.18378/rvads.v9i4.2951

YARNELL, E.; ABASCAL, K. Botanical treatment and prevention of malaria: Part-2-Selected botanicals. Alternative and Complementary Therapies, v.10, n.6, p.277-284, 2004. http://dx.doi.org/10.1089/act.2004.10.277 